\title{
PENGARUH MODAL KERJA, ASET, DAN OMZET PENJUALAN TERHADAP LABA UKM CATERING DI WILAYAH SURAKARTA
}

\author{
SUPRIHATMI SRI WARDININGSIH \\ Fakultas Ekonomi Universitas Slamet Riyadi Surakarta \\ e-mail: suprihatmi60@gmail.com \\ RETNO SUSANTI \\ Fakultas Ekonomi Universitas Slamet Riyadi Surakarta \\ e-mail: tnos_santi@yahoo.com
}

\begin{abstract}
Abstrak
This study aimed to determine the effect of working capital, asset, and sales turnover to profits of SMEs. The population in this study is catering SMEs (Small and Medium Enterprises) at Surakarta located in the five districts. The sample in this study are catering SMEs in Surakarta consist of 92 SMEs. The data in this study using secondary data from the quarterly financial statements of catering SMEs in Surakarta on 2015 that fully include working capital, fixed assets, sales turnover and profit. Result of this research show that working capital have positive and significant effect on SMEs profits, means Hypothesis 1 is accepted. Assets no significant effect on SMEs profit means Hypothesis 2 was rejected. Sales turnover have positive and significant effect on SMEs profit means Hypothesis 3 is accepted. Implications of this research, increase in working capital and sales turnover have a positive contribution on profits of SMES catering in Surakarta.
\end{abstract}

Kata kunci: working capital, assets, sales turnover, SMEs profit.

\section{PENDAHULUAN}

Peran UKM sangat penting dalam pembangunan perekonomian di Indonesia, terutama dalam penyediaan tenaga kerja dan sumber penghasilan bagi kelompok masyarakat yang berpenghasilan rendah. Sektor UKM memiliki peranan yang sangat strategis baik sosial ekonomi dan politis, dengan menyediakan barang dan jasa bagi konsumen berdaya beli rendah sampai sedang. UKM juga membantu Pemerintah dalam upaya pemberantasan kemiskinan melalui pengembangan perekonomian sistem kerakyatan (Sukesti dan Nurhayati, 2015: 207). Keberadaan Usaha Kecil dan Menengah (UKM) memiliki peran penting dan memiliki kontribusi positif pada perekonomian nasional dan daerah, selain dapat menyerap tenaga kerja juga turut berperan dalam proses pemerataan dan peningkatan pendapatan masyarakat. Sejalan dengan hal tersebut pengembangan UKM amat penting dilakukan, dan salah satu perhatian pemerintah diantaranya adalah turut mendukung penyaluran kredit modal kerja bagi pelaku UKM. Bagi setiap organisasi usaha, modal memegang peranan penting di dalam menjalankan operasi usaha. Modal merupakan bagian hak pemilik dalam perusahaan yaitu selisih aktiva dan utang yang ada (Mardiasmo, 2008: 36). 
Usaha catering adalah istilah umum untuk wirausaha yang melayani pemesanan berbagai macam masakan dan minuman yang melibatkan perlengkapan untuk kebutuhan acara pesta maupun instansi yang disiapkan pada waktu dan tempat tertentu. Kenyataan yang terjadi sekarang ini beberapa industri catering rumahan telah berkembang dan melayani beberapa acara pernikahan dalam ukuran yang besar Dengan berkembangnya permintaan atas jasa catering maka banyak UKM-UKM catering baru yang terjun ke bidang ini sehingga membuat UKM-UKM catering mengalami tantangan untuk mempertahankan keberadaannya dan juga mengembangkan usahanya (Samir \& Larso, 2011: 164). Perkembangan usaha catering juga terjadi di kota Surakarta, sehingga bertambahnya jusaha catering ini memberikan kontribusi pada peningkatan jumlah UKM di Surakarta.

Kemampuan UKM catering di Surakarta untuk bertahan ataupun tumbuh dan berkembang harus dilihat dari kinerja UKM tersebut. UKM usaha catering di Surakarta pada umumnya sangat memperhatikan laba atau keuntungan yang diharapkan, hal ini sangat penting agar UKM dapat mempertahankan kontinuitas atau kelangsungan hidup usahanya. Menurut Husnan (2001: 180) laba adalah kemampuan suatu perusahaan dalam menghasilkan keuntungan (profit) pada tingkat penjualan, aset, dan modal saham tertentu. Laba sering kali menjadi salah satu ukuran kinerja perusahaan, dimana ketika perusahaan memiliki laba yang tinggi berarti kinerjanya akan lebih baik, demikian sebaliknya. Laba perusahaan selain merupakan indikator kemampuan perusahaan memenuhi kewajiban bagi para penyandang dana juga merupakan elemen dalam penciptaan nilai perusahaan yang menunjukkan prospek perusahaan di masa yang akan datang (Horne dan Wachowicz, 2013: 89).

Inayah dkk (2014: 2) menyatakan tidak sedikit UKM yang awalnya telah mampu membangun usahanya dengan baik, tetapi karena terkendala dana atau modal menyebabkan usahanya tidak bisa berkembang, sehingga kehidupan mereka tidak ada kemajuan dari segi ekonomi. Wiksuana dkk. (2001: 95) menyatakan modal menjadi penting karena dengan modal perusahaan dapat melaksanakan kegiatan operasionalnya dan melakukan pengembangan atau perluasan usaha. Dengan demikian, adanya modal kerja yang cukup memungkinkan bagi perusahaan UKM untuk beroperasi secara maksimal dan tidak mengalami kesulitan akibat krisis keuangan. Pentingnya peran modal kerja dalam sebuah UKM digunakan untuk membiayai kegiatan operasionalnya dan mengembangkan bisnis adalah solusi mengenai permasalahan umum yang dihadapi UKM (Sukesti \& Nurhayati, 2015: 208).

Faktor lain yang mempengaruhi laba usaha UKM adalah aset, bertambahnya aset umumnya menyebabkan laba usaha akan bertambah tinggi, namun hal ini tergantung pada kemampuan perusahaan untuk melakukan efisensi biaya, maupun kemampuan untuk mengoperasikan dan mengelola aset yang tersedia (Winarko, 2014: 152). Aset adalah sarana atau sumber daya ekonomik yang dimiliki oleh suatu perusahaan yang harga perolehannya atau nilai wajarnya harus diukur secara objektif (Munawir, 2007: 30). Laba yang dicapai UKM juga dapat dipengaruhi besar kecilnya volume usaha atau omzet penjualan. Volume usaha adalah total nilai penjualan atau penerimaan dari barang dan jasa pada suatu periode atau tahun buku yang bersangkutan (Sitio dan Tamba, 2001:141).

Penelitian Sukesti \& Nurhayati (2015) menunjukkan bahwa modal kerja berpengaruh signifikan terhadap kinerja keuangan UKM makanan kecil di kota Semarang. Hasil penelitian 
yang dilakukan oleh Muhdin (2010) menunjukkan bahwa modal kerja berpengaruh signifikan terhadap perolehan laba operasi PT Indosat Tbk. Hasil penelitian yang dilakukan oleh Paranesa dkk (2016) menunjukkan bahwa penjualan dan modal sendiri berpengaruh signifikan terhadap laba usaha pada UD Aneka Jaya Motor di Singaraja. Hasil penelitian yang dilakukan oleh Winarko (2014) aset, modal sendiri, dan jumlah anggota berpengaruh signifikan terhadap sisa hasil usaha pada koperasi di kota Kediri. Hasil penelitian yang dilakukan oleh Ganitri dkk (2014) modal sendiri, modal pinjaman, dan volume usaha berpengaruh signifikan terhadap selisih hasil usaha pada koperasi simpan pinjam.

Tujuan yang ingin dicapai dalam penelitian ini adalah sebagai berikut:

1. Untuk menganalisis signifikansi pengaruh modal kerja terhadap laba UKM catering di wilayah Surakarta.

2. Untuk menganalisis signifikansi pengaruh aset terhadap laba UKM catering di wilayah Surakarta.

3. Untuk menganalisis signifikansi pengaruh omzet penjualan terhadap laba UKM catering di wilayah Surakarta.

Hipotesis yang diajukan dalam penelitian ini adalah sebagai berikut:

1. Modal kerja berpengaruh signifikan terhadap laba UKM catering di Surakarta.

2. Aset berpengaruh signifikan terhadap laba UKM catering di Surakarta.

3. Omzet penjualan berpengaruh signifikan terhadap laba UKM catering di Surakarta.

\section{METODE PENELITIAN}

Jenis penelitian ini adalah penelitian survey dengan menggunakan pendekatan kuantitatif, di mana analisis data yang dilakukan dalam penelitian ini dengan melakukan perhitungan statistik. Desain/rancangan penelitian ini adalah tipe eksplanatori yaitu menjelaskan hubungan kausal antara variabel-variabel melalui pengujian hipotesis. Populasi dalam penelitian ini seluruh UKM catering di Surakarta. Untuk ukuran populasi yang tidak teridentifikasi, maka untuk menentukan ukuran sampel penelitian digunakan rumus Leedy:

$$
N=\left(\frac{Z}{e}\right)^{2}(P)(1-P)
$$

Dari hasil perhitungan diperoleh jumlah sampel sebanyak 100 responden. Metode penentuan sampel menggunakan purposive sampling. Kriteria sampel yang ditetapkan dalam penelitian ini, UKM catering yang memiliki laporan keuangan lengkap dalam bentuk laporan triwulan tahun 2015. Menurut Arikunto (2006: 139) teknik purposive sampling (sampel bertujuan) adalah cara mengambil sampel yang didasarkan karena tujuan tertentu yang didasarkan oleh pertimbangan peneliti sendiri sehingga dapat mewakili populasi.

Modal kerja adalah besarnnya modal yang dimiiki UKM catering di wilayah Surakarta untuk membiayai kegiatan operasional usaha dihitung dalam satuan rupiah per triwulan. Aset adalah aktiva tetap yang dimiliki UKM catering di wilayah Surakarta untuk menjalankan usaha dihitung dalam satuan rupiah per triwulan. Omzet penjualan adalah keseluruhan jumlah penjualan barang/jasa dalam kurun waktu tertentu, yang dihitung berdasarkan jumlah uang yang diperoleh UKM catering di wilayah Surakarta dalam satuan rupiah per triwulan. Laba adalah keuntungan bersih yang dihasilkan UKM catering di wilayah Surakarta dihitung dari selisih antara jumlah penerimaan usaha catering dengan biaya produksi dan biaya lain dalam satuan rupiah per triwulan. 
Teknik pengumpulan data dalam penelitian ini menggunakan dokumentasi, berupa data triwulan yang disajikan pada laporan keuangan UKM catering Surakarta tahun 2015. Uji Asumsi Klasik dilakukan melalui empat uji yaitu uji multikolinieritas, uji autokorelasi, uji heteroskedastisitas, dan uji normalitas. Teknik analisis data menggunakan analisis regresi linier berganda bertujuan untuk mengetahui pengaruh modal kerja, aset, dan omzet penjualan terhadap laba UKM yang dinyatakan dengan persamaan sebagai berikut:

$Y=a+\beta 1 X 1+\beta_{2} X_{2}+\beta_{3} X_{3}+e$

Keterangan:

Y

$X_{1} \quad:$ Modal kerja

$\mathrm{X}_{2} \quad:$ : Aset

$\mathrm{X}_{3} \quad:$ : Omzet penjualan

a $\quad$ : konstanta

$\beta_{1} \ldots \beta_{3} \quad:$ Koefisien regresi

e : : Standar error

Pengujian hipotesis dilakukan melalui uji t dengan menggunakan tingkat signifikansi $5 \%$. Uji $\mathrm{F}$ bertujuan untuk menguji ketepatan model dan dan uji koefisien determinasi bertujuan untuk mengetahui persentase sumbangan pengaruh modal kerja, aset, dan omzet penjualan terhadap laba UKM

\section{HASIL DAN PEMBAHASAN}

Populasi dalam penelitian ini adalah Usaha Kecil Menengah (UKM) catering yang berlokasi di kota Surakarta tersebar di lima kecamatan yaitu Jebres, Banjarsari, Lawiyan, Serengan, dan Pasar Kliwon. Sampel dalam penelitian ini Usaha Kecil Menengah (UKM) catering di Surakarta sebanyak 100 UKM. Data yang akan dianalisis dalam penelitian ini bersumber dari data sekunder berupa laporan keuangan triwulan UKM catering Surakarta pada tahun 2015 yang secara lengkap menyertakan modal kerja, aset tetap, omzet penjualan, dan perolehan laba. Dalam pelaksanaannya tidak semua UKM bersedia memberikan laporan keuangan secara lengkap, dari 100 UKM (100\%) yang bersedia memberikan laporan keuangan secara lengkap sebanyak 92 UKM (92\%). Pada tahap analisis selanjutnya, data yang akan dianalisis menggunakan data triwulan dari 92 sampel UKM sehingga jumlah data (cases) seluruhnya adalah 368 cases. Hasil perolehan sampel penelitian disajikan seperti tabel berikut.

\section{Tabel 1. Data Sampel}

\begin{tabular}{clcc}
\hline No. & \multicolumn{1}{c}{ Keterangan } & $\begin{array}{c}\text { Jumlah } \\
\text { (UKM) }\end{array}$ & Persentase \\
\hline 1 & Jumlah sampel yang ditetapkan & 100 & $100 \%$ \\
2 & $\begin{array}{l}\text { UKM tidak memiliki laporan keuangan } \\
\text { lengkap }\end{array}$ & 8 & $8 \%$ \\
3 & UKM memiliki laporan keuangan lengkap & 92 & $92 \%$ \\
\hline
\end{tabular}

Sumber: Data primer diolah, 2016

Data variabel yang digunakan dalam penelitian ini adalah laba (variabel dependen), sedangkan data variabel independen terdiri dari tiga variabel yaitu modal kerja, aset, dan 
omzet penjualan. Statistik deskriptif bertujuan untuk mengetahui kecenderungan sebaran data masing-masing variabel menurut nilai minimum, nilai maksimum, nilai rata-rata (mean), dan standard deviasi dengan hasil seperti tabel berikut.

Tabel 2. Statistik Deskriptif

\begin{tabular}{lrrrc}
\hline & Laba & Modal Kerja & \multicolumn{1}{c}{ Aset } & Omzet Penjualan \\
\hline Max & 129.000 .000 & 894.000 .000 & 975.000 .000 & 1.690 .000 .000 \\
Min & 39.820 .000 & 245.000 .000 & 93.170 .000 & 310.000 .000 \\
Mean & 72.182 .814 & 408.835 .484 & 306.615 .323 & 497.845 .161 \\
Std & 17.463 .561 & 120.727 .013 & 138.891 .250 & 203.789 .699 \\
\hline
\end{tabular}

Sumber: Data primer diolah, 2016

Hasil uji multikolinieritas menunjukkan bahwa masing-masing variabel independen (modal kerja, aset dan omzet penjualan) tidak saling berkorelasi linier ditunjukkan dengan dengan nilai tolerance $(0,363 ; 0,952 ; 0,363)>0,1$ dan nilai VIF $(2,757 ; 1,051 ; 2,753)<$ 10. Hal ini diartikan bahwa model regresi linier berganda tidak terjadi masalah multikolinieritas. Perhitungan uji autokorelasi dilakukan melalui uji Runs. Kriteria pengujian, apabila Asymp.Sig.(2-tailed) > 0,05 maka model regresi bebas dari masalah autokorelasi (Ghozali, 2005: 95). Hasil uji Runs dengan program SPSS menghasilkan probabilitas atau Asymp.Sig.(2-tailed) sebesar 0,296 > 0,05. Dengan demikian model regresi linier berganda dalam penelitian ini tidak terjadi masalah autokorelasi. Perhitungan uji heteroskedastisitas dilakukan melalui uji Glejser. Ketentuan tidak terjadi heteroskedastisitas jika $p$ value $>0,05$ sebaliknya jika $p$ value $\leq 0,05$ maka terjadi heteroskedastisitas (Ghozali, 2005: 108). Hasil uji Glejser dengan program SPSS menunjukkan bahwa masing-masing variabel independen (modal kerja, aset dan omzet penjualan) tidak signifikan terhadap variabel absolut residual. Hal ini ditunjukkan dengan $p$ value $(0,474 ; 0,497 ; 0,768)>0,05$, berarti model regresi linier ganda dalam penelitian ini tidak terjadi masalah heteroskedastisitas. Perhitungan uji normalitas dilakukan melalui uji Kolmogorov-Smirnov. Kriterianya, apabila nilai signifikan statistik yang dihasilkan dari perhitungan uji Kolmogorov-Smirnov menghasilkan Asymp.Sig.(2-tailed) > 0,05 maka variabel pengganggu atau residual berdistribusi normal, sebaliknya apabila Asymp.Sig.(2-tailed) $\leq$ 0,05 maka variabel pengganggu atau residual tidak berdistribusi normal. (Ghozali, 2005: 115). Uji Kolmogorov-Smirnov dengan program SPSS menghasilkan Asymp.Sig.(2-tailed) sebesar 0,088 > 0,05 berarti residual normal.

\section{Tabel 3. Hasil Uji Asumsi Klasik}

\begin{tabular}{|c|c|c|}
\hline $\begin{array}{l}\text { Uji Asumsi } \\
\text { Klasik }\end{array}$ & Hasil Uji & Kesimpulan \\
\hline $\begin{array}{l}\text { Uji } \\
\text { multikolinieritas }\end{array}$ & $\begin{array}{l}\text { Tolerance }(0,363 ; 0,952 ; 0,363)> \\
0,1 \text { dan nilai VIF }(2,757 ; 1,051 ; \\
2,753)\end{array}$ & $\begin{array}{l}\text { Tidak terjadi } \\
\text { multikolinieritas }\end{array}$ \\
\hline Uji autokorelasi & Asymp.Sig.(2-tailed) 0,296 > 0,05 & $\begin{array}{l}\text { Tidak terjadi } \\
\text { autokorelasi }\end{array}$ \\
\hline $\begin{array}{l}\text { Uji } \\
\text { heteroskedastisit } \\
\text { as }\end{array}$ & $\begin{array}{l}p \text { value }(0,474 ; 0,497 ; 0,768)> \\
0,05\end{array}$ & $\begin{array}{l}\text { Tidak ada } \\
\text { heteroskedastisitas }\end{array}$ \\
\hline
\end{tabular}


Uji normalitas

Asymp.Sig.(2-tailed) sebesar

Residual normal

$0,088>0,05$

Sumber: Data primer diolah, 2016

Berdasarkan analisis regresi linier berganda dengan program SPSS diperoleh hasil seperti tabel berikut.

\section{Tabel 4. Hasil Analisis Regresi Linier Berganda}

\begin{tabular}{lccc}
\hline \multicolumn{1}{c}{ Variabel Independen } & Koefisien regresi & Nilai t & Signifikansi \\
\hline Konstanta & 10,549 & & \\
Modal kerja $(\mathrm{X} 1)$ & 0,176 & 2,311 & 0,021 \\
\hline Aset $(\mathrm{X} 2)$ & 0,021 & 0,957 & 0,339 \\
\hline Omzet Penjualan $(\mathrm{X} 3)$ & 0,183 & 3,084 & 0,002 \\
\hline $\mathrm{F}: 25,601$ & & & 0,000 \\
Adjusted $\mathrm{R}^{2}: 0,167$ & & & \\
\hline
\end{tabular}

Sumber: Data primer diolah, 2016

Berdasarkan hasil tersebut diperoleh persamaan regresi:

$Y=10,549+0,176 X_{1}+0,021 X_{2}+0,183 X_{3}$

Persamaan regresi tersebut dapat diartikan sebagai berikut :

$\mathrm{a}=10,549$ artinya jika modal kerja, aset dan omzet penjualan $=0$ maka besarnya laba UKM adalah sebesar 10,549 persen.

$b_{1}=0,176$ artinya jika modal kerja meningkat sebesar 1 persen maka laba UKM akan meningkat sebesar 0,176 \% dengan asumsi variabel aset dan omzet penjualan dianggap konstan.

$b_{2}=0,021$ artinya jika aset meningkat sebesar 1 persen maka laba UKM akan meningkat sebesar 0,021 persen dengan asumsi variabel modal kerja dan omzet penjualan dianggap konstan.

$b_{3}=0,183$ artinya jika omzet penjualan meningkat sebesar 1 persen maka laba UKM akan meningkat sebesar 0,183 persen dengan asumsi variabel modal kerja dan aset dianggap konstan.

Uji signifikansi pengaruh modal kerja terhadap laba UKM diperoleh p value $(0,020)<$ 0,05 maka $\mathrm{H}_{\mathrm{o}}$ ditolak berarti modal kerja berpengaruh signifikan terhadap laba UKM. Semakin tinggi modal kerja maka laba UKM akan semakin tinggi. Dengan demikian hipotesis 1 diterima atau terbukti kebenarannya. Pengaruh aset terhadap laba UKM Uji signifikansi pengaruh aset terhadap laba UKM diperoleh $\mathrm{p}$ value $(0,339)>0,05$ maka $\mathrm{H}_{\mathrm{o}}$ diterima berarti aset tidak berpengaruh signifikan terhadap laba UKM. Dengan demikian hipotesis 2 ditolak atau tidak terbukti kebenarannya. Uji signifikansi pengaruh omzet penjualan terhadap laba UKM diperoleh $\mathrm{p}$ value $(0,002)<0,05$ maka $\mathrm{H}_{0}$ ditolak berarti omzet penjualan berpengaruh signifikan terhadap laba UKM. Semakin tinggi omzet penjualan maka laba UKM akan semakin tinggi. Dengan demikian hipotesis 3 diterima atau terbukti kebenarannya.

Berdasarkan hasil Analysis of Variance (ANOVA) diperoleh nilai $\mathrm{F}$ hitung sebesar 25,601 dengan $p$ value $(0,000)<0,05$ artinya model regresi linier berganda dinyatakan tepat (fit) dalam memprediksi pengaruh modal kerja, aset dan omzet penjualan terhadap 
laba UKM. Berdasarkan analisis regresi linier berganda diketahui bahwa besarnya nilai Adjusted $R$ Square adalah 0,167 artinya sumbangan pengaruh modal kerja, aset dan omzet penjualan terhadap laba UKM adalah sebesar $16,7 \%$, sisanya sebesar $83,3 \%$ dijelaskan variabel lain yang tidak diteliti.

Hasil temuan penelitian ini menunjukkan bahwa modal kerja berpengaruh positif dan signifikan terhadap laba UKM catering di Surakarta. Semakin tinggi modal kerja yang digunakan dalam menjalankan usaha maka laba yang dicapai UKM setiap triwulan akan semakin tinggi. Modal kerja merupakan elemen yang paling utama dalam keberlangsungan suatu perusahaan, dimana sebagai sumber awal yang digunakan untuk menjalankan aktivitas operasi sehingga mencapai laba yang diharapkan. Pengusaha UKM catering di Surakarta dalam menjalankan usahanya perlu memiliki kas. Kas tersebut disimpan sendiri dalam bentuk uang tunai ataupun ditabung di bank. Besar kecilnya modal kerja yang dimiliki UKM tentunya akan mempengaruhi kemampuan pengusaha dalam membelanjai kegiatan operasional sehari-hari. Berdasarkan temuan penelitian ini penggunaan modal kerja memberikan pengaruh positif dan signifikan terhadap laba UKM di catering di Surakarta sehingga peningkatan modal kerja memberikan efek pada peningkatan laba UKM. Implikasi dari temuan penelitian ini, laba UKM di catering di Surakarta dapat ditingkatkan melalui peningkatan modal kerja. Temuan penelitian ini mendukung penelitian Sukesti \& Nurhayati (2015) bahwa modal kerja berpengaruh signifikan terhadap kinerja keuangan UKM makanan kecil di kota Semarang. Temuan penelitian ini mendukung penelitian Muhdin (2010) bahwa modal kerja berpengaruh signifikan terhadap perolehan laba operasi PT Indosat Tbk. Temuan penelitian ini mendukung penelitian Paranesa dkk (2016) bahwa penjualan dan modal sendiri berpengaruh signifikan terhadap laba usaha pada UD Aneka Jaya Motor di Singaraja. Hasil penelitian Ganitri dkk (2014) menunjukkan bahwa modal sendiri, modal pinjaman, dan volume usaha berpengaruh signifikan terhadap selisih hasil usaha pada koperasi simpan pinjam. Temuan penelitian ini mendukung penelitian Saragih \& Nasution (2014) bahwa modal kerja berpengaruh signifikan terhadap pendapatan pengusaha UMKM di Kabupaten Toba Samosir. Temaun ini juga sejalan dengan penelitian Priyandika (2015) bahwa modal kerja berpengaruh positif dan signifikan terhadap pendapatan pedagang kaki lima pedagang konveksi di Kecamatan Semarang Tengah Kota Semarang.

Hasil temuan penelitian ini menunjukkan bahwa aset berpengaruh positif dan signifikan terhadap laba UKM catering di Surakarta. Semakin tinggi aset yang digunakan dalam menjalankan usaha maka laba yang dicapai UKM setiap bulannya akan semakin tinggi. Keberhasilan UKM catering di Surakarta di antaranya dapat dilihat dari semakin meningkatnya jumlah keuntungan. UKM dalam menjalankan usaha catering perlu memiliki aset atau aktiva yang memadai, di mana aset merupakan kekayaan yang dimiliki oleh perusahaan yang dapat menjamin berlangsungnya kegiatan perusahaan. Aset memiliki peran penting dalam mendukung kegiatan operasional perusahaan, sehingga tanpa aset sebuah perusahaan tidak dapat melakukan kegiatan-kegiatannya tersebut. Aset yang dimaksud dalam penelitian ini adalah aktiva tetap yang dimiliki UKM catering di wilayah Surakarta untuk menjalankan usaha dihitung dalam satuan rupiah per triwulan. Aset tetap yang dimiliki UKM catering di Surakarta dapat berbentuk bangunan, kendaraan, peralatan untuk kegiatan produksi, dan sebagainya. Dengan demikian bertambahnya aset tetap yang dimiliki UKM catering Surakarta akan mempengaruhi besarnya kekayaan perusahaan dalam 
mendukung kapasitas usaha, sehingga laba yang diperoleh umumnya akan semakin bertambah. Temuan penelitian ini tidak sejalan dengan penelitian Winarko (2014) bahwa aset berpengaruh signifikan terhadap peningkatan sisa hasil usaha pada koperasi di kota Kediri. Tidak terdukungnya hipotesis 2 dalam penelitian ini dapat disebabkan karena pengelolaan aset tetap yang dilakukan UKM catering di Surakarta masih belum optimal. Kenyataan yang dialami, dalam setiap triwulan beberapa UKM catering di Surakarta memiliki aset tetap yang cukup besar namun semua itu tergantung dari kapasitas produksi yang ditentukan jumlah order. Dengan demikian apabila pesanan menurun, maka nilai aset tetap akan semakin berkurang. Kenyataan lain disebabkan karena peningkatan pengeluaran untuk aset tetap tidak sebanding dengan kegiatan produksi sehingga keuntungan yang diperoleh menjadi kurang optimal.

Hasil temuan penelitian ini menunjukkan bahwa omzet penjualan berpengaruh positif dan signifikan terhadap laba UKM catering di Surakarta. Semakin tinggi omzet penjualan maka keuntungan bersih atau laba yang dicapai UKM setiap triwulannya akan semakin tinggi. Penjualan merupakan salah satu kegiatan dalam pemasaran, dengan kata lain sasaran utama dari pemasaran adalah untuk memperoleh peningkatan penjualan dari waktu ke waktu dalam periode tertentu. Dalam penelitian ini, omzet penjualan yang dicapai UKM catering di Surakarta adalah keseluruhan jumlah pendapatan yang didapat dari hasil penjulan barang/jasa selama satu bulan. Tinggi rendahnya omzet penjualan selain ditinjau dari faktor modal, juga dapat dipengaruhi oleh kemampuan pengusaha dalam pemasaran, kondisi pasar dan faktor-faktor lain seperti kondisi pesaing dan kebijakan pemerintah. Peningkatan omzet penjualan UKM catering di Surakarta perlu memperhatikan dua faktor utama yaitu faktor internal dan eksternal. Faktor internal yaitu berasal dari pihak pengusaha UMKM sendiri seperti kemampuan pemasaran amat penting untuk dikembangkan, dalam hal ini UKM perlu memperhatikan strategi pemasaran misalnya dengan meningkatkan pelayanan konsumen, memberikan diskon, pemberian hadiah atau melakukan promosi melalui iklan. Implikasi dari hasil temuan penelitian ini bahwa peningkatan laba UKM catering di Surakarta dapat ditingkatkan melalui peningkatan jumlah omzet penjualan. Pengusaha UKM yang ingin meningkatkan keuntungan perlu meningkatkan persediaan barang atau kapasitas produksinya sehingga omzet penjualan diharapkan akan semakin besar. Kenyataan yang terjadi, untuk meningkatkan omzet penjualan diperlukan modal besar untuk membiayai kegiatan produksi, apabila modal usaha tidak memadai para UKM catering di Surakarta mencari pinjaman melalui kredit bank, koperasi atau lembaga keuangan lain yang memberikan bunga yang kompetitif. Temuan penelitian ini mendukung penelitian Ganitri dkk (2014) bahwa volume usaha berpengaruh signifikan terhadap selisih hasil usaha pada koperasi simpan pinjam. Temuan penelitian ini mendukung penelitian Zaini (2010) bahwa jumlah penerimaan berpengaruh positif dan signifikan terhadap pendapatan petani padi sawah di Loa Gagak Kabupaten Kutai Kartanegara. 


\section{KESIMPULAN}

Berdasarkan hasil pengujian setiap hipotesis, diperoleh kesimpulan (1) Modal kerja berpengaruh positif dan signifikan terhadap laba UKM catering di Surakarta dengan $p$ value 0,021 berarti Hipotesis 1 diterima. Setiap kenaikan modal kerja dapat mempengaruhi peningkatan laba UKM catering di Surakarta. (2) Aset tidak berpengaruh signifikan terhadap laba UKM catering di Surakarta dengan $p$ value 0,339 berarti Hipotesis 2 ditolak. Variabel aset memiliki koefisien regresi positif, artinya setiap kenaikan aset dapat mempengaruhi peningkatan laba UKM catering di Surakarta. (3) Omzet penjualan berpengaruh positif dan signifikan terhadap laba UKM catering di Surakarta dengan $p$ value 0,002 berarti Hipotesis 3 diterima. Setiap kenaikan omzet penjualan dapat mempengaruhi peningkatan laba UKM catering di Surakarta.

Modal kerja merupakan elemen penting dalam membiayai kegiatan produksi. Untuk memperoleh laba yang besar, UKM catering di Surakarta perlu meningkatkan modal kerja Peningkatan modal kerja dapat diupayakan melalui tambahan modal asing berupa pinjaman (kredit) dari koperasi atau lembaga keuangan dengan suku bunga yang ringan. Pengusaha UKM Catering di Surakarta disarankan perlu meninjau ulang terhadap aset tetap yang dimiliki, untuk selanjutnya aset tetap harus dikelola dengan efektif dan efisien. Beberapa cara antara lain menyediakan jenis persediaan yang memang dibutuhkan sesuai dengan kapasitas produksi, atau menjual aset tetap yang tidak perlu. Peningkatan laba UKM ditentukan dari besarnya omzet penjualan. Untuk meningkatkan omzet penjualan, UKM catering di Surakarta disarankan untuk meningkatkan kegiatan pemasaran melalui promosi. Kegiatan promosi dapat dilakukan dengan menayangkan iklan di media cetak atau online, serta menyebar brosur pada acara pesta perkawinan, seminar, ulang tahun, atau hajatan lain Koperasi dan lembaga keuangan perbankan disarankan turut berperan dalam membantu akses permodalan Usaha Kecil Menengah melalui pelayanan yang mudah dan cepat serta suku bunga yang ringan.

\section{DAFTAR PUSTAKA}

Arikunto, S., (2006), Prosedur Penelitian, Edisi Revisi VI, Jakarta: Rineka Cipta.

Ganitri, P.T., Suwendra, I.W., dan Yulianthini, N.N., (2014), "Pengaruh Modal Sendiri, Modal Pinjaman, dan Volume Usaha terhadap Selisih Hasil Usaha (SHU) pada Koperasi Simpan Pinjam", e-Journal Bisma, Jurusan Manajemen Universitas Pendidikan Ganesha Denpasar, Vol. 2, Hal. 1-10.

Ghozali, I., (2005), Aplikasi Analisis Multivariate dengan Program SPSS, Semarang: Badan Penerbit Universitas Diponegoro.

Horne, J.C.V., dan Wachowicz, J.M.Jr., (2013), Prinsip-prinsip Manajemen Keuangan, Edisi Kesembilan, Jakarta: Salemba Empat.

Husnan, S., (2001), Laba, Cetakan Kelima, Yogyakarta: UPP STIM YKPN.

Inayah, N., Kirya, I.K., dan Suwendra, I.W., (2014), "Pengaruh Kredit Modal Kerja terhadap Pendapatan Bersih Usaha Kecil dan Menengah (UKM) Sektor Formal', e-Journal Bisma, Jurusan Manajemen Universitas Pendidikan Ganesha Denpasar, Vol. 2, Hal. 1-8. 
Mardiasmo, (2008), Akuntansi Keuangan Dasar I; Dilengkapi dengan Soal dan Penyelesaiannya, Yogyakarta: BPFE.

Muhdin, (2010), "Analisis Pengaruh Kebijakan Modal Kerja terhadap Perolehan Laba", Ganeq Swara, Edisi Khusus Vol. 4 (3), Desember, Hal. 1-8.

Munawir, (2007), Analisa Laporan Keuangan, Edisi delapan, Yogyakarta: Liberty.

Paranesa, G.N., Cipta, W., dan Yulianthini, N.N., (2016), "Pengaruh Penjualan dan Modal Sendiri terhadap Laba pada UD Aneka Jaya Motor di Singaraja", e-Journal Bisma, Jurusan Manajemen Universitas Pendidikan Ganesha Denpasar, Vol. 4, Hal. 1-7.

Samir, A., dan Larso, D., (2011), "Identifikasi Faktor-Faktor yang Mempengaruhi Kinerja UKM Catering di Kota Bandung", Jurnal Manajemen Teknologi, Vol. 10 (2), Hal. 162184.

Sukesti, F., dan Nurhayati, (2015), "Strategi Pengembangan UKM melalui Peningkatan Modal Kerja dengan Variabel Intervening Pengembangan Bisnis pada UKM Makanan Kecil di Kota Semarang", The $2^{\text {nd }}$ University Research Coloquium 2015, Universitas Muhammadiyah Semarang. Hal. 207-216.

Supriyono, R A., (2002), Akuntansi Manajemen, Jakarta: Salemba Empat.

Wiksuana, B., Wiagustini dan Sedana, P., (2001), Buku Ajar Manajemen Keuangan, Denpasar: Universitas Udayana.

Winarko, S.P., (2014), "Pengaruh Modal Sendiri, Jumlah Anggota dan Aset terhadap Sisa Hasil Usaha pada Koperasi di Kota Kediri", Nusantara of Research, Vol. 1 (2), Oktober, Hal. 151-167. 